\title{
IAMJ
}

INTERNATIONAL

AYURVEDIC

MEDICAL JOURNAL

\section{A CLINICAL STUDY TO EVALUATE THE EFFICACY OF PUSHKARMULADI CHURNA IN THE MANAGEMENT OF VATAJA KASA W.S.R. TO RECURRENT U.R.T.I. IN CHILDREN}

\author{
Aarti Semwal', Keerti Verma², ${ }^{1}$ Sujatha ${ }^{3}$ \\ ${ }^{1}$ PG Scholar, Dept of Kaumarbhritya, Rishikul Campus Uttarakhand Ayurveda University, Dehradun, UK, India \\ ${ }^{2}$ Professor and Head, Dept of Kaumarbhritya, Rishikul Campus Uttarakhand Ayurveda University Dehradun, UK, \\ India \\ ${ }^{3}$ Associate Professor, Dept of Kaumarbhritya, Patanjali Ayurvigyan Sansthan, Uttarakhand Ayurveda University \\ Dehradun, UK, India
}

Corresponding Author: $\underline{\text { aarti.semwal273@gmail.com }}$

\section{https://doi.org/10.46607/iamj0708092020}

(Published online: September 2020)

Open Access

(C) International Ayurvedic Medical Journal, India 2020

Article Received: 14/08/2020 - Peer Reviewed: 01/09/2020 - Accepted for Publication: 05/09/2020

Check for updates

\section{ABSTRACT}

Respiratory disorders are the most frequently occurring illness in childhood and the most common medical reason for school or work absenteeism. Vataja Kasa is one of the commonest Symptom of the respiratory illness in Paediatric age. Recurrent attacks make the school going child suffer and may hamper the optimum growth and development of child. The present Open label single blind clinical trial was carried out to evaluate the effect of Pushkarmuladi Churna in Vataja Kasa in children. The clinical trial included 30 patients belonging age group of 1 to 16 years. The drug was administered in a daily fixed dose as per "Sharangdhar Samhita" along with Madhu for duration of 30 days. There was five follow up and patients were followed up at the interval of every 7 days and 1 month after the completion of the study. The results were analysed statistically. After full observation of treatment modules, it was found that no one patient was found unchanged and no one patient with mild improvement. Whereas moderate improvement was observed in 1 patient $(8.69 \%)$, marked improvement was observed in 8 patients $(26.66 \%)$, and complete improvement was observed in 21 patients $(70 \%)$. The analysis suggested that the 
Pushkarmuladi Churna is effective and safe herbal formulation in reducing the signs and symptoms of Vataja Kasa.

Keywords: Vataja Kasa, Cough, Pushkarmuladi Churna.

\section{INTRODUCTION}

Good health is considered to be root of the objects of human life. Disease stands as a great obstacle in the achievement of good health. Respiratory Disease afflicts every human being at some time in their life. Whether it's a cough associated with the common cold or respiratory distress associated with allergies and asthma, respiratory challenges are a constant source of irritation and misery for the afflicted.

One of the unique criteria of living activity is breathing and the basic activity of Pranavahasrotas is exchange of gases. The rate of exchange of gases is to tune of 16 times per minute making it one of the most vulnerable sites for disease. Prana and Apana or to say breathing out and breathing in are the sine que non-phenomenon of life. To and fro movement of air through the Pranavahasrotas is the vital sign of Pra$n a$, the normalcy of which suggests health. The abnormality of respiration indicates disease, and its cessation marks death. This unique sign of life is affected in the disease Kasa.

Kasa is one of the commonest complains in day to day practice and is also a symptom of various systemic diseases. Kasa has been described as an independent disorder as well as symptom of many diseases. It is the disease or symptom of respiratory tract occurring due to obstruction of Vata Dosha and its reverse movement. Kasa seems to be a very simple disease. If neglected or mis-managed, it may result in disease with poor prognostic condition. In Ayurveda Kasa is considered as an independent disease unlike in modern science. It may also occur as a Lakshana or an Upadrava in other diseases.

Kasa in Ayurveda is of 5 types ${ }^{[1]}$. Among them, Vataja Kasa though is not life threatening, it troubles the person as it hinders the day to day activity. This problem has been compounded by our modern life style, urbanization, industrialization, pollution and population explosion as a result of which "Dhuma" and
"Raja" are the main causes of Pranavahasroto Dush$t i$, which have become unavoidable, making Kasa the most commonest disease to the extent of $60 \%$ of total diseases being recorded.

A lot of modern disease entities can be included under the heading of Vataja Kasa. The disease entity Recurrent Upper Respiratory Tract Infections (RURTIs) are going almost hand in hand with the Vataja Kasa. Cough is the cardinal symptom of URTI. It is a critical and a complex physiological defense mechanism which helps in protecting the respiratory system. It can occur due to the irritation and inflammation of the upper respiratory tract, which includes throat and wind pipe ${ }^{[2]}$.

According to the report of WHO expert committee on comprehensive school health education and promotion, recurrent infections are a major cause of decreased school performance and school absenteeism in developing as well as developed countries ${ }^{[3]}$. Upper Respiratory Tract Infections account for a good percentage of the same.

Coming to the management, Sequential administration of the Snehana, Swedana, Shodhana, Dhoopana, Shamana and Rasayana line of treatment forms the complete treatment of Kasa expounded in the Ayurvedic literature. Among these procedures, the Shamana line of treatment that includes oral administration of medicine and as the administration is very easy, it is considered better compared to Shodhana. Many more herbal combinations are described in Ayurveda and their therapeutic effect in Kasa is yet to be explored. Pushkarmuladi Churna is one such herbal combination mentioned in Bhaishjya Ratnawali Under Bal Rogadhikar ${ }^{[4]}$, the efficacy of which is still to be proved by modern research methods. It is explained specially in the context of Panch Kasa in children as Shamanaoushadha. By looking into each constituent of Pushkarmuladi Churna, it appears that this combi- 
nation is likely to be very effective in combating the sign and symptoms of Vataja Kasa.

Taking this into consideration, the present research work entitled is planned to evaluate the relative merit of the oral administration of the Pushkarmuladi Churna with Madhu.

\section{Aim and Objectives}

a) To analyze the etiopathogenesis of Vataja Kasa and Recurrent URTI's.

b) To evaluate the efficacy of Pushkarmuladi Churna in the management of Vataja Kasa.

c) To provide a safe and cost-effective herbal formulation for the management of Vataja Kasa.

\section{- Materials \& Methods}

Thirty-five patients in between age group of 1 to 16 years diagnosed with Vataja Kasa (URTI) after detailed clinical history and physical examination, were selected from the O.P.D and I.P.D department of Kaumarbhritya, Rishikul Campus, Haridwar. Among these, 5 patients left the treatment before the completion of the therapy. Hence, the final assessment of the result was done only in 30 patients. The study was
Open label single blind type. Duration of study was 2 months after registration, divided in one-month study with drug followed by another one month without drug to know the recurrence of disease. There was five follow up and patients were followed up at the interval of every 7 days and 1 month after the completion of the study. Ethical clearance from the Institutional Ethical Committee was obtained and trail was also registered under Clinical Trial Registry of India.

(CTRI/2019/04/018374).

\section{- Preparation Of The Drug}

Required raw drugs (Pushkarmula, Ativisha, Karkatshringi, Pippali, Dhanvayas) were collected from Hans Pharmacy \& identified by Dravyaguna Department of Rishikul Campus, Haridwar. The Pushkarmuladi Churna were prepared in the Hans Pharmacy Sidcul, Haridwar.

\section{- Investigations}

Total Leucocyte Count, Differential Leukocyte Count, Erythrocyte Sedimentation Rate, Absolute Eosinophil Count.

\section{- Subjective Parameters (Table 1-8)}

(Special Note: - Grade- 3 to 0 shows severe to normal condition of parameters)

Table 1. Severity of Cough

\begin{tabular}{|c|c|c|c|c|}
\hline Parameter & Grade 3 & Grade 2 & Grade 1 & Grade 0 \\
\hline $\begin{array}{l}\text { Severity of } \\
\text { Cough }\end{array}$ & $\begin{array}{l}\text { Severe and hacking cough with No } \\
\text { sputum expectorated and associat- } \\
\text { ed with dryness of mouth, throat } \\
\text { and chest. }\end{array}$ & $\begin{array}{l}\text { Moderate cough with } \\
\text { difficulty in expul- } \\
\text { sion of sputum }\end{array}$ & $\begin{array}{l}\text { Mild cough with small quan- } \\
\text { tity of sputum expectorated } \\
\text { at the end of a bout. }\end{array}$ & $\begin{array}{l}\text { No cough at } \\
\text { all }\end{array}$ \\
\hline
\end{tabular}

Table 2: Severity of bouts.

\begin{tabular}{|l|l|l|l|l|}
\hline Parameter & \multicolumn{1}{|c|}{ Grade 3 } & \multicolumn{1}{|c|}{ Grade 2 } & Grade 1 & Grade 0 \\
\hline $\begin{array}{l}\text { Severity of } \\
\text { bouts }\end{array}$ & $\begin{array}{l}\text { Vomiting at the end of cough } \\
\text { with cyanosis of face. }\end{array}$ & $\begin{array}{l}\text { Face becomes red at the } \\
\text { end of Cough. }\end{array}$ & $\begin{array}{l}\text { Normal bouts with no dis- } \\
\text { coloration of face. }\end{array}$ & No bouts. \\
\hline
\end{tabular}

Table 3: Severity of frequency.

\begin{tabular}{|l|c|c|c|c|}
\hline Parameter & Grade 3 & Grade 2 & Grade 1 & Grade 0 \\
\hline Frequency of bouts & More than 10 bouts. & About $5-10$ bouts & About 1-5 bouts. & No bouts. \\
\hline
\end{tabular}

Table 4: Chest pain.

\begin{tabular}{|l|c|c|c|l|}
\hline Parameter & Grade 3 & Grade 2 & Grade 1 & Grade 0 \\
\hline Chest pain & Continues and persistent chest pain. & Pain during entire bout of cough. & Occasional chest pain & Absent. \\
\hline
\end{tabular}


Table 5: Headache.

\begin{tabular}{|l|l|l|l|l|}
\hline Parameter & \multicolumn{1}{|c|}{ Grade 3 } & Grade 2 & \multicolumn{1}{|c|}{ Grade 1 } & Grade 0 \\
\hline Headache & Severe Constant headache. & $\begin{array}{l}\text { Frequent headache but not } \\
\text { severe. }\end{array}$ & $\begin{array}{l}\text { Occasional headache at } \\
\text { the time of cough. }\end{array}$ & No headache. \\
\hline
\end{tabular}

Table 6. Hoarseness of voice

\begin{tabular}{|l|l|l|l|l|} 
Parameter & \multicolumn{1}{|c|}{ Grade 3 } & \multicolumn{1}{|c|}{ Grade 2 } & Grade 1 & Grade 0 \\
\hline $\begin{array}{l}\text { Hoarseness of } \\
\text { voice }\end{array}$ & $\begin{array}{l}\text { Can't make sound due to } \\
\text { hoarseness of voice. }\end{array}$ & $\begin{array}{l}\text { Hoarseness of voice present } \\
\text { but no difficulty in speech. }\end{array}$ & $\begin{array}{l}\text { Hoarseness of voice only } \\
\text { at the time of cough. }\end{array}$ & $\begin{array}{l}\text { No Hoarseness } \\
\text { of voice. }\end{array}$ \\
\hline
\end{tabular}

Table 7: Sore throat.

\begin{tabular}{|l|l|l|l|l|}
\hline Parameter & \multicolumn{1}{|c|}{ Grade 3 } & Grade 2 & \multicolumn{1}{|c|}{ Grade 1 } & Grade 0 \\
\hline Sore throat & $\begin{array}{l}\text { Sore throat with pain which inter- } \\
\text { fere the intake of food along with } \\
\text { water. }\end{array}$ & $\begin{array}{l}\text { Sore throat with pain and } \\
\text { difficulty in food intake. }\end{array}$ & $\begin{array}{l}\text { Sore throat with pain but no } \\
\text { difficulty in food intake. }\end{array}$ & $\begin{array}{l}\text { No } \\
\text { throat. }\end{array}$ \\
\hline
\end{tabular}

Table 8: Sleep disturbance.

\begin{tabular}{|l|l|l|l|l|}
\hline Parameter & \multicolumn{1}{|c|}{ Grade 3 } & \multicolumn{1}{|c|}{ Grade 2 } & \multicolumn{1}{|c|}{ Grade 1 } & Grade 0 \\
\hline $\begin{array}{l}\text { Sleep disturb- } \\
\text { ance }\end{array}$ & $\begin{array}{l}\text { Cough always } \\
\text { disturbs sleep. }\end{array}$ & $\begin{array}{l}\text { Gets cough before sleeping and or } \\
\text { wakes the child in morning. }\end{array}$ & $\begin{array}{l}\text { Cough occasionally } \\
\text { disturbs sleep. }\end{array}$ & $\begin{array}{l}\text { Cough don't inter- } \\
\text { fere the sleep. }\end{array}$ \\
\hline
\end{tabular}

\section{- Result}

Statistical analysis: -To obtain the efficacy of the therapy proper Statistical analysis was carried out by applying Wilcoxon test on subjective parameters and Paired t-test on objective parameters. The information collected on the basis of observations was analyzed using appropriate statistical test to evaluate the significances at different levels i.e. at 0.05, 0.01 and 0.001 levels. The obtained results were interpreted as:-pvalue $>0.05$ : - Not significant, $p$-value $<0.05$ : Significant, $\mathrm{p}$-value $<0.01$ : -Very significant, $p$ value $<0.001$ : -Highly significant

Table 9: Overall Effect of Therapy on Subjective Parameters

\begin{tabular}{|l|l|l|l|l|l|l|l|}
\hline Symptoms & \multicolumn{2}{|c|}{ Mean Score } & D & Relief \% & W & P & Significance \\
\hline & B.T & A.T & & & & & \\
\hline Severity of Cough & 1.86 & 0.33 & 1.53 & 82.14 & -435.000 & $<0.001$ & HS \\
\hline Severity of bouts & 1.46 & 0.23 & 1.23 & 84.09 & -406.000 & $<0.001$ & HS \\
\hline Frequency of bouts & 1.56 & 0.23 & 1.33 & 85.10 & -465.000 & $<0.001$ & HS \\
\hline Chest pain & 1.17 & 0.41 & 0.76 & 65 & -66.000 & $<0.001$ & HS \\
\hline Headache & 1.26 & 0.52 & 0.73 & 58.62 & -153.000 & $<0.001$ & HS \\
\hline Hoarseness of voice & 1.33 & 0.33 & 1 & 75 & -300.000 & $<0.001$ & HS \\
\hline Sore throat & 1.23 & 0.61 & 0.61 & 50 & -78.000 & $<0.001$ & HS \\
\hline Sleep disturbance & 1.64 & 0.10 & 1.53 & 93.47 & -378.000 & $<0.001$ & HS \\
\hline
\end{tabular}

Table 10: Overall Effect of Therapy on Objective Parameters

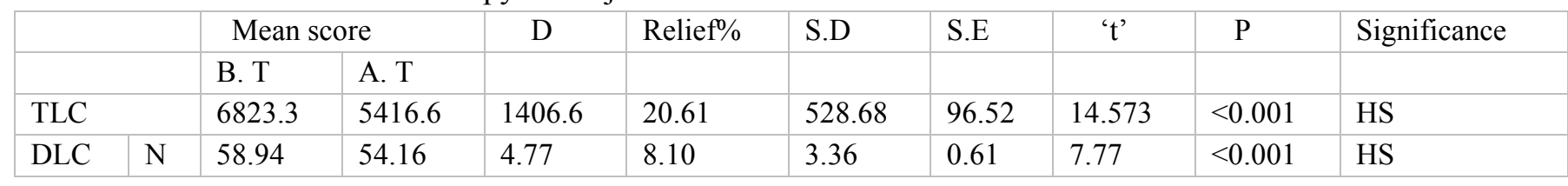




\begin{tabular}{|c|c|c|c|c|c|c|c|c|c|c|}
\hline & $\mathrm{L}$ & 39.66 & 35.9 & 3.76 & 9.48 & 4.13 & 0.75 & 4.98 & $<0.001$ & HS \\
\hline & $\mathrm{E}$ & 4.65 & 2.66 & 1.98 & 42.69 & 1.08 & 0.19 & 10.02 & $<0.001$ & HS \\
\hline & $\mathrm{M}$ & 1.1 & 1.04 & 0.06 & 5.15 & 0.24 & 0.04 & 1.29 & $>0.05$ & NS \\
\hline & B & 0.05 & 0.05 & 0 & 0 & 0 & 0 & 0 & $>0.05$ & NS \\
\hline \multicolumn{2}{|l|}{ E.S.R. } & 12.033 & 8.99 & 3.10 & 25.76 & 1.00 & 0.18 & 11.54 & $<0.001$ & HS \\
\hline \multicolumn{2}{|l|}{ A.E.C. } & 447 & 411 & 36.16 & 8.08 & 18.92 & 3.45 & 10.46 & $<0.001$ & HS \\
\hline
\end{tabular}

Table 11: Total Effect of Treatment Modules

\begin{tabular}{|l|l|l|}
\hline Results & Group & \% \\
\hline Complete Improvement & 21 & 70 \\
\hline Marked Improvement & 8 & 26.66 \\
\hline Moderate Improvement & 1 & 8.69 \\
\hline Mild Improvement & 0 & 0 \\
\hline Unchanged & 0 & 0 \\
\hline
\end{tabular}

\section{DISCUSSIONS}

Age group -There were $51.42 \%$ were belonging to age group of $1-5$ year. $34.28 \%$ of patients were belonging to age group of $6-10$ year and $14.28 \%$ in 11 16 year of age group. This is because of the increased incidence of upper respiratory tract infection during this period. In essence it is the increased production of mucus in the upper respiratory tract and it most frequently follows infection and allergic reactions. As the immunity is also low in lower group so we get more incidence of recurrence in lower age group.

Sex- $71.42 \%$ patients were male while rest of the patients i.e. $28.57 \%$ were female. This may be because of exposure to dust and allergens during high activities of male children.

Socio-economic Distribution - It revealed that prevalence of Kasa was more in (42.85\%) Lower middleclass children. Socio economic status has an effect on a child's response to illness. If they are poor and the diet is inadequate, a child's resistance will be lower. In case of meeting the health care expenditure of child including immunization and maintaining hygienic residential conditions also the socioeconomic status play a role. This could be due to the presence of residence or the school in polluted atmosphere like dust, smoke, etc. and living in a congested place without proper ventilation, which plays a contributory role in the production of Kasa.

Immunization: Most of the patients were immunized according to their age i.e. $97.14 \%$, only $2.85 \%$ of pa- tients were remained Un-immunized. It is due to increased awareness of Immunization. The children were given immunization against dreadful disease such as polio, Hib, diphtheria, mumps measles etc. However other disease-causing organisms can still attack the patients and cause disease.

In all the three groups the effect of treatment was highly significant ( $\mathrm{p}$-value $<0.001)$ in all the subjective parameters of Vataja Kasa. On the hematological parameter, the trial drug showed highly significant except Monocyte and Basophils i.e. not significant. Percentage of relief was found most in Eosinophil count. So, it may be inferred that drug is more effective in allergic conditions.

The drug, Pushkarmuladi Churna consists of ingredients which balancing each other in Rasa panchaka and enhancing the Vata- Kaphahara, Deepana, Pachana and Vatanuloman properties. and gave relief in Vataja kasa.

\section{CONCLUSION}

Vataja Kasa vis a vis Recurrent Upper Respiratory Tract Infections is a common problem of all age groups. It gives rise to a good number of long term as well as short-term complications that can hamper the overall growth of a child. The decreased immunity as well as digestive power of people in the current era that have arisen because of improper food habits and industrialization. Children are more susceptible to RURTI / Kasa due to their premature / immature sta- 
tus of Agni, Bala and Ojas. The trial drug was effective specifically in preventing the complications of further episodes, relieving the conditions quicker during winter season and preventing the recurrence throughout winter. At the end of course of study all the subjective parameters show highly significant result, as $p$ value is $<0.001$. Maximum $\%$ of relief found in sleep disturbance i.e. $93.47 \%$ with satisfactory relief in Severity of Cough (82.14\%), Severity of bouts $(84.09 \%)$, Frequency of bouts $(85.10 \%)$. All objective parameter also shows highly significant result except Monocyte and basophil having not significant result. Maximum \% of relief on Eosinophil count i.e. $42.69 \%$. At the end of trial, $70 \%$ complete improvement found followed by marked improvement i.e. $26.66 \%$ and $8.69 \%$ moderate improvement. The effect of Pushkarmuladi Churna preventing on Vataja Kasa could be explained in terms of the Deepana, Pachana, Srotoshodhana property of the combination. The antiinflammatory drugs working against the inflammation of airways also might have contributed effectively to remove Srotodushti. Some of the ingredients having Rasayan properties have contributed to enriched status of Dhatus at the presence of increased Agni.

\section{ACKNOWLEDGEMENT}

I sincerely acknowledge my gratitude to my mentor and respected guide Prof. (Dr.) Keerti Verma, H.O.D. for her divine encouragement \& valuable guidance during all research work

\section{REFERENCES}

1. Charak Samhita of Agnivesha, revised by Charaka and Drdhabala, Chikitsa Sthana 18/4, Page No.532.

2. www.healthplus24.com.

3. World Health Organization. Promoting Health Through Schools. WHO Geneva 1997: 7 - 21.

4. Shri govind Das- Bhaisajyaratnavali, Balrogadhikar, $.71 / 75$

\section{Source of Support: Nil}

Conflict of Interest: None Declared

How to cite this URL: Aarti Semwal et al: A Clinical Study To Evaluate The Efficacy Of Pushkarmuladi Churna In The Management Of Vataja Kasa W.S.R. To Recur-rent U.R.T.I. In Children. International Ayurvedic Medical Journal \{online\} 2020 \{cited September, 2020\} Available from: http://www.iamj.in/posts/images/upload/4342_4347.pdf 